\section{Differential Cold Acclimation Ability of Petunia spp.}

\author{
Aaron E. Walworth and Ryan M. Warner, \\ Department of Horticulture, Michigan State University, A234 Plant and Soil \\ Science, East Lansing, MI 48824
}

Additional index words. electrolyte leakage, freezing tolerance, photoperiod

\begin{abstract}
Freezing tolerance of many plant species increases after exposure to low, nonfreezing temperatures, a process termed cold acclimation. In some species, shortened photoperiods also bring about an increase in freezing tolerance. Within the plant family Solanaceae, species vary widely in cold acclimation ability. The objectives of this work were to examine the effects of low temperature and photoperiod on cold acclimation of Petunia hybrida (Hook.) Vilm. 'Mitchell' and to evaluate cold acclimation of several Petunia species by measuring freezing tolerance using an electrolyte leakage assay on leaf tissue discs. Temperature, but not photoperiod, influenced cold acclimation of $P$. hybrida. Whether grown under long days or short days, nonacclimated plants had an EL $_{50}$ value (temperature at which $50 \%$ of cellular electrolytes are lost) of $\approx-2{ }^{\circ} \mathrm{C}$. Plants acclimated by gradual cooling at temperatures of $15^{\circ} \mathrm{C}, 10^{\circ} \mathrm{C}$, and $3{ }^{\circ} \mathrm{C}$ for 7 days each reached an $\mathbf{E L}_{50}$ of $\approx-5^{\circ} \mathrm{C}$ regardless of photoperiod. Exposure to $3^{\circ} \mathrm{C}$ under short days for 1 or 3 weeks resulted in $\mathrm{EL}_{50}$ temperatures of -3.9 and $-4.9^{\circ} \mathrm{C}$, respectively. Freezing tolerance of petunia species $P$. exserta Stehmann, $P$. integrifolia (Hook.) Schinz \& Thell., $P$. axillaris (Lam.) Britton et al. (USDA accessions 28546 and 28548), and $P$. hybrida 'Mitchell' was similar before cold acclimation, but varied from $-5{ }^{\circ} \mathrm{C}$ for $P$. exserta to $-8{ }^{\circ} \mathrm{C}$ for $P$. axillaris (accession 28548) after cold acclimation. Our results demonstrate the cold acclimation ability of Petunia spp. and identify wild germplasm sources with potential usefulness for improving freezing tolerance of cultivated petunia.
\end{abstract}

Plants endure many biotic and abiotic stresses, including exposure to cold temperatures. Tremendous damage to plant cells can result from freezing temperatures, primarily to the cellular membranes (Thomashow, 1999). Many plants have adapted to life in cooler climates by developing mechanisms to tolerate low temperatures, but cold tolerance is a dynamic characteristic. When grown in warm temperatures, even cold-hardy plants have low freezing tolerance. Exposure to low nonfreezing temperatures brings about an increase in freezing tolerance through a process termed cold acclimation (Thomashow, 1999). Within the family Solanaceae, even within the genus Solanum, species vary considerably in their ability to cold-acclimate. The chilling-sensitive $S$. lycopersicum L. (tomato) and freezing-sensitive $S$. tuberosum L. (potato) do not cold acclimate (Chen and Li, 1980; Hsieh et al., 2002; Pino et al., 2007), whereas $S$. commersonii Dun. (a wild potato relative) is frost-tolerant and capable of acclimation (Chen and Li, 1980; Pino et al., 2008). Petunia hybrida does cold acclimate (Pennycooke et al., 2003; Yelenosky and Guy, 1989), whereas cold acclimation ability of other Petunia spp. is currently unknown.

Received for publication 2 Feb. 2009. Accepted for publication 27 Apr. 2009.

We gratefully acknowledge financial support from the Michigan Agricultural Experiment Station Project GREEEN and the American Floral Endowment. ${ }^{1}$ Assistant Professor.

${ }^{2}$ To whom reprint requests should be addressed; e-mailwarnerry@msu.edu.
Cold acclimation brings about changes in gene expression (Guy et al., 1985) and cellular metabolite profiles (Cook et al., 2004), resulting in survival at temperatures much lower than would be tolerated without acclimation. Stabilizing cellular membranes against dehydration resulting from extracellular ice formation is a critical component of cold acclimation. Electrolyte leakage assays provide a simple method to assess cellular membrane integrity of plants exposed to abiotic stresses, including low temperature (Pennycooke et al., 2003; Sukumaran and Weiser, 1972; Thapa et al., 2008). Typically, the temperature resulting in $50 \%$ of maximum electrical conductivity (EC; i.e., membrane injury) is reported (Palta et al., 1978).

In addition to exposure to low nonfreezing temperatures, shortened photoperiods induce cold acclimation of many woody plant species (Howell and Weiser, 1970; Li et al., 2002; Marian et al., 2004) and some herbaceous species such as Hordeum vulgare L. 'Dicktoo' (Fowler et al., 2001) and Gaura coccinea Pursh. (Pietsch et al., 2009). In Betula pendula Roth, both a shortened photoperiod $(12 \mathrm{~h})$ and low temperatures $\left(4^{\circ} \mathrm{C}\right)$ result in acclimation, but low temperatures produce a stronger response, whereas simultaneous exposure to low temperatures and short days produces an additive response $(\mathrm{Li}$ et al., 2002). Freezing tolerance of $H$. vulgare 'Dicktoo' was greater for plants exposed to $4{ }^{\circ} \mathrm{C}$ under an 8 -h photoperiod compared with a 20-h photoperiod (Fowler et al., 2001). The effects of photoperiod and temperature on cold acclimation of Petunia hybrida are currently unknown.
Garden petunias ( $P$. hybrida) are a very popular bedding plant, ranking first in sales among bedding plants in 2007 with a wholesale value of over $\$ 111$ million (U.S. Department of Agriculture-National Agricultural Statistics Service, 2008). Although Petunia hybrida does cold-acclimate, the acclimation only improves freezing tolerance by $\approx 2.5^{\circ} \mathrm{C}$ (Pennycooke et al., 2003). Further improving freezing tolerance of petunia would benefit both consumers and commercial growers. The selection of bedding plants suited for growth in early spring and late fall, when cold night temperatures and frosts still limit the survival of most bedding plants, is limited. During the processes of domestication and breeding, the genetic diversity of a plant species tends to decrease dramatically (Tanksley and McCouch, 1997). Strong selection imposed by plant breeders, along with crossing between closely related individuals, leads to a narrowing of the genetic diversity in future generations. Using wild germplasm has proven to be an effective method for crop improvement. In the genus Petunia, interspecific crosses usually produce fertile progeny (Ando et al., 2001; Griesbach, 2007), making use of wild germplasm possible. Griesbach et al. (1999) determined that the red color of $P$. exserta results from genetic factors distinct from those in current red-colored $P$. hybrida cultivars. Interspecific hybridization using $P$. exserta is adding to the genetic diversity of P. hybrida (Griesbach et al., 1999).

The objectives of the current study are 1) to examine the effects of low temperature and photoperiod on cold acclimation of $P$. hybrida; and 2) to evaluate cold acclimation of $P$. axillaris, $P$. integrifolia, $P$. exserta, and $P$. hybrida 'Mitchell' in an effort to identify genetic material that may be useful in breeding more stress-tolerant cultivars.

\section{Materials and Methods}

Plant growth and cold acclimation conditions. Seeds of P. hybrida 'Mitchell' were surface-planted onto 288-cell plug trays filled with $70 \%$ peatmoss, $21 \%$ perlite, and $9 \%$ vermiculite (v/v) (Suremix; Michigan Grower Products Inc., Galesburg, MI). Trays were placed under intermittent overhead mist irrigation at $23{ }^{\circ} \mathrm{C}$ until the development of two true leaves. Plants were then transferred to a greenhouse at $22{ }^{\circ} \mathrm{C}$ with a 16 -h photoperiod (ambient plus $50 \mu \mathrm{mol} \cdot \mathrm{m}^{-2} \cdot \mathrm{s}^{-1}$ supplemental high-pressure sodium lighting from 0600 to $2200 \mathrm{HR}$ ) for 3 weeks. Seedlings were then transplanted to 50-cell trays containing the same soilless media and moved to a controlled environment growth chamber at $22{ }^{\circ} \mathrm{C}$ under a 16 -h photoperiod $\left[115 \pm 7 \mu \mathrm{mol} \cdot \mathrm{m}^{-2} \cdot \mathrm{s}^{-1}\right.$ (mean \pm SD) photosynthetically active radiation provided by fluorescent plus incandescent lighting] for 1 week. To determine the influence of photoperiod and temperature on cold acclimation, 50 plants were subjected to each of seven different treatments described in Table 1.

In a second experiment, $P$. integrifolia, $P$. exserta (kindly provided by Dr. Rob 
Table 1. Growth conditions [temperature, photoperiod, photosynthetic photon flux $(P P F)$ and duration] of P. hybrida 'Mitchell' plants before electrolyte leakage assays.

\begin{tabular}{lcccc}
\hline Growth regimes & $\begin{array}{c}\text { Temperature } \\
\left({ }^{\circ} \mathrm{C}\right)\end{array}$ & $\begin{array}{c}\text { Photoperiod } \\
(\mathrm{h})\end{array}$ & $\begin{array}{c}P P F \\
\left(\mu \mathrm{mol} \cdot \mathrm{m}^{-2} \cdot \mathrm{s}^{-1}\right)\end{array}$ & $\begin{array}{c}\text { Duration } \\
(\text { weeks })\end{array}$ \\
\hline Nonacclimated LD (NONLD) & 22 & 16 & 115 & 6 \\
Nonacclimated SD (NONSD) & 22 & 16 & 115 & 4 \\
& 22 & 9 & 115 & 3 \\
Cold acclimation 1 (CA1) & 22 & 16 & 115 & 6 \\
& 3 & 9 & 30 & 1 \\
Cold acclimation 2 (CA2) & 22 & 16 & 115 & 4 \\
& 22 & 9 & 115 & 2 \\
Cold acclimation 3 (CA3) & 3 & 9 & 30 & 1 \\
RampdownSD & 22 & 16 & 115 & 5 \\
& 3 & 9 & 30 & 3 \\
& 22 & 16 & 115 & 1 \\
RampdownLD & 15 & 9 & 115 & 1 \\
& 10 & 9 & 115 & 1 \\
& 3 & 9 & 30 & 5 \\
& 22 & 16 & 115 & 1 \\
& 15 & 16 & 115 & 1 \\
\hline
\end{tabular}

$\mathrm{LD}=$ long day; $\mathrm{SD}=$ short day

Griesbach, USDA-ARS), two accessions of $P$. axillaris (USDA accessions 28546 and 28548; obtained from the USDA Ornamental Plant Germplasm Center, Columbus, OH), and P. hybrida 'Mitchell' were sown as described previously. When seedlings had developed two true leaves, plants were transferred to a greenhouse at $20{ }^{\circ} \mathrm{C}$ with a 16 -h photoperiod (as described previously) for 4 weeks. Seedlings were then transplanted into 50-cell trays and moved to a controlled environment growth chamber at $22{ }^{\circ} \mathrm{C}$ with a 16 -h photoperiod $\left(115 \pm 7 \mu \mathrm{mol} \cdot \mathrm{m}^{-2} \cdot \mathrm{s}^{-1}\right)$. After 2 weeks, plants of each species were divided into two groups: a nonacclimated group remaining at $22{ }^{\circ} \mathrm{C}$ for an additional week before testing and a cold-acclimated group. Cold acclimation was induced following a protocol previously described to be effective for $P$. hybrida (RampdownSD; Pennycooke et al., 2003). Plants were moved to $15{ }^{\circ} \mathrm{C}$ with a 9 -h photoperiod $(115 \pm 7$ umol $\cdot \mathrm{m}^{-2} \cdot \mathrm{s}^{-1}$ ) for 1 week followed by $10{ }^{\circ} \mathrm{C}$ with a 9 -h photoperiod $\left(115 \pm 7 \mu \mathrm{mol} \cdot \mathrm{m}^{-2} \cdot \mathrm{s}^{-1}\right.$ light) for 1 week, and finally $3{ }^{\circ} \mathrm{C}$ with a $9-\mathrm{h}$ photoperiod ( $30 \pm 3 \mu \mathrm{mol} \cdot \mathrm{m}^{-2} \cdot \mathrm{s}^{-1}$ light) for an additional week. Within each chamber, trays were rerandomized approximately every 3 $\mathrm{d}$ to minimize the effects of variable irradiance. The irradiance level at $3{ }^{\circ} \mathrm{C}$ was kept low to minimize the potential for photooxidative stress (Wise and Naylor, 1987). At the time of testing, nonacclimated plants were 7 weeks old and acclimated plants were 9 weeks old. However, plants in both groups had developed approximately the same number of nodes at the time of sampling.

Determination of freezing tolerance. Freezing tolerance of leaves was determined by the method of Sukumaran and Weiser (1972) with slight modifications. After temperature/photoperiod treatments, leaf discs from the upper portion of the plant were collected using a 6-mm cork borer and rinsed by floating on deionized water $\left(\mathrm{dH}_{2} \mathrm{O}\right)$ with gentle stirring. The youngest leaves allowing a complete 6-mm diameter disc to be har- vested without cutting into the midrib were sampled. Approximately 120 punches were taken from a population of 50 plants for each treatment. Three discs were transferred to each of 30 glass culture tubes per treatment and placed on ice. Tubes were placed in $\mathrm{a}-1^{\circ} \mathrm{C}$ controlled-temperature antifreeze-filled bath (master bath) for $60 \mathrm{~min}$. Three tubes of each treatment remained on ice as controls. After $60 \mathrm{~min}$, a small amount of ice was added to each tube for extracellular ice nucleation. Tubes were plugged with foam and kept at $-1{ }^{\circ} \mathrm{C}$ for an additional $60 \mathrm{~min}$, after which three tubes of each treatment were moved to a second antifreeze bath at $-1{ }^{\circ} \mathrm{C}$, kept there for $40 \mathrm{~min}$, and removed to ice. Meanwhile, the temperature of the master bath was lowered to $-2{ }^{\circ} \mathrm{C}$. After $20 \mathrm{~min}$, three tubes of each treatment were moved from the master bath to another antifreeze bath at $-2{ }^{\circ} \mathrm{C}$ for $40 \mathrm{~min}$ and then removed to ice (a total of $60 \mathrm{~min}$ at the test temperature). This process continued for all temperatures tested $\left(-1\right.$ to $\left.-9{ }^{\circ} \mathrm{C}\right)$. Tubes were then put in racks on top of ice and placed at $2.5^{\circ} \mathrm{C}$ to thaw slowly overnight. The next day, $6 \mathrm{~mL}$ of $\mathrm{dH}_{2} \mathrm{O}$ was added to each tube followed by gentle shaking for $3 \mathrm{~h}$ at room temperature. The water was transferred to a new culture tube and EC (L1) was measured using a CON 110 conductivity meter (Oakton Instruments, Vernon Hills, IL). Plant discs remained in the original tube and were frozen to $-80{ }^{\circ} \mathrm{C}$ overnight. The next day, the water from the previously measured tubes was poured back into the corresponding plant disc tube followed by shaking for $3 \mathrm{~h}$ at room temperature. Conductivity of the water was measured again to obtain the reading for maximum electrolyte leakage (L2). Percent of maximum electrolyte leakage at each test temperature was calculated as: percent leakage $=(\mathrm{L} 1 / \mathrm{L} 2) \times$ 100.

Data analysis. Data were analyzed using Sigmaplot (SPSS Inc., Chicago, IL) and SAS (SAS Institute Inc., Cary, NC) software. A sigmoidal curve was fit to the leakage data for each treatment according to the equation: $y=$ $a 1+\{a 2 /[1+\exp (a 3-a 4 \times T)]\}$, where $y$ is the average percent electrolyte leakage of the three tubes at each temperature $(T)$ using the curve fitting function of Sigmaplot. The initial parameters were specified as $a 1=0.1$, $a 2=99.9, a 3=0.1$, and $a 4=0.1$ with constraints imposed such that $a 1>0$ and $0<a 2<100$. The temperature at which $50 \%$ of maximal conductivity was reached $\left(\mathrm{EL}_{50}\right)$ was calculated by solving the equation $\mathrm{EL}_{50}=$ $\{a 3-\log [a 2 /(50-a 1)]-1\} / a 4$, where the parameters $a 1, a 2, a 3$, and $a 4$ are given by the equation of the fitted curve. At least two $\mathrm{EL}_{50}$ values were calculated for each treatment from two separate replications of the experiment. Analysis of variance and mean separations using Fisher's least significant difference ( $\alpha=0.05)$ were conducted on the $\mathrm{EL}_{50}$ values using PROC GLM from SAS to compare treatment effects.

\section{Results}

Influence of environmental cues on cold acclimation. Temperature regime, but not photoperiod, influenced cold acclimation of P. hybrida 'Mitchell' (Fig. 1). When grown at $22{ }^{\circ} \mathrm{C}$ and 16-h long days (NONLD), $P$. hybrida 'Mitchell' $\mathrm{EL}_{50}$ value was $-1.9{ }^{\circ} \mathrm{C}$. Exposing plants to 3 weeks of short days alone (NONSD) did not increase freezing tolerance and the $\mathrm{EL}_{50}$ temperature remained at $-2.0^{\circ} \mathrm{C}$. Gradual cooling, in which plants were grown under a 16-h photoperiod for $7 \mathrm{~d}$ each at temperatures of 15,10 , and $3{ }^{\circ} \mathrm{C}$ (RampdownLD) resulted in significant cold acclimation, because the $\mathrm{EL}_{50}$ temperature decreased to $-5.1{ }^{\circ} \mathrm{C}$. Plants exposed to the same cooling regime under 9-h days (RampdownSD) exhibited similar cold acclimation as Rampdown $\mathrm{LD}$ with an $\mathrm{EL}_{50}$ temperature of $-5.0{ }^{\circ} \mathrm{C}$.

Moving plants directly from long days at $22{ }^{\circ} \mathrm{C}$ to short days at $3{ }^{\circ} \mathrm{C}$ for just 1 week (CA1) increased freezing tolerance slightly $\left(\mathrm{EL}_{50}=-3.9^{\circ} \mathrm{C}\right)$ compared with NONLD and NONSD (Fig. 1). Increasing the time of exposure to $3{ }^{\circ} \mathrm{C}$ under short days from 1 to 3 weeks (CA3) further increased freezing tolerance $\left(\mathrm{EL}_{50}=-4.9^{\circ} \mathrm{C}\right)$ compared with the CA1 treatment. Exposing plants to short days at $22{ }^{\circ} \mathrm{C}$ for 2 weeks before exposure to $3{ }^{\circ} \mathrm{C}$ with short days for 1 week (CA2) resulted in an $\mathrm{EL}_{50}$ value of $-4.0^{\circ} \mathrm{C}$, similar to CA1 (Fig. 2). Exposure to 3 weeks of gradual cooling in both the RampdownSD and RampdownLD treatments resulted in the same degree of cold acclimation as 3 weeks at $3{ }^{\circ} \mathrm{C}$ (CA3; Fig. 1). However, the RampdownSD and RampdownLD treatments were more effective than the CA1 treatment with just 1 week at $3{ }^{\circ} \mathrm{C}$.

Cold acclimation ability of Petunia species. All species tested had similar constitutive freezing tolerance (Fig. 2) with an $\mathrm{EL}_{50}$ temperature of $\approx-2{ }^{\circ} \mathrm{C}$ without cold acclimation. Acclimated $\mathrm{EL}_{50}$ temperatures varied across species. The most freezingtolerant species was $P$. axillaris (USDA accession 28548) with an acclimated $\mathrm{EL}_{50}$ 


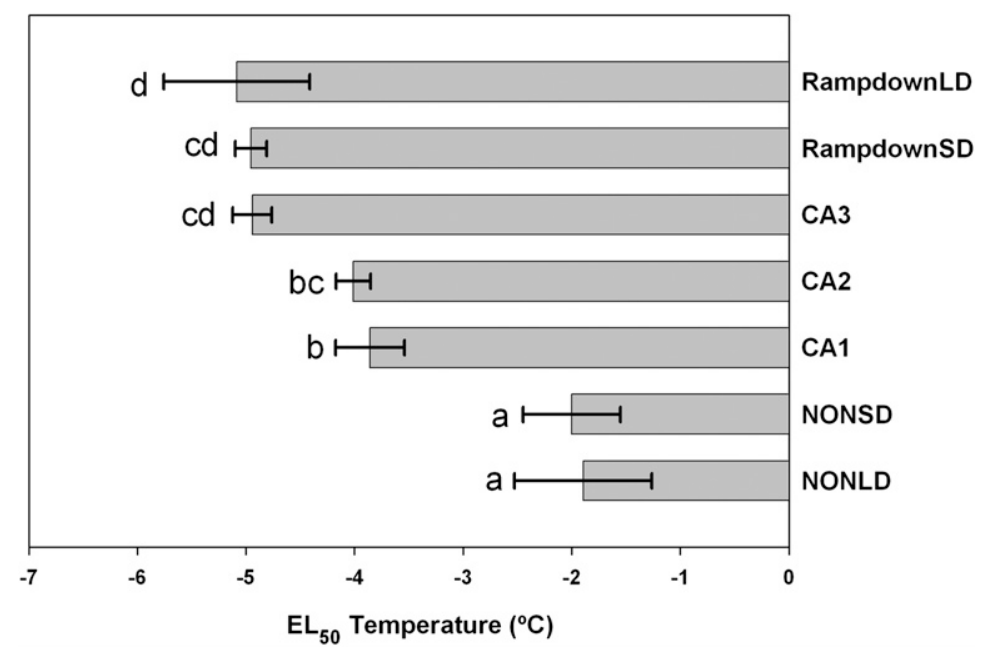

Fig. 1. Freezing tolerance $\left[\mathrm{EL}_{50}\right.$ (temperature at which $50 \%$ of maximum electrolyte leakage occurred)] for P. hybrida 'Mitchell' after various cold acclimation regimes. NONLD $=22^{\circ} \mathrm{C}$, long day $(\mathrm{LD} ; 16-\mathrm{h}$ long days). NONSD $=22{ }^{\circ} \mathrm{C}, \mathrm{LD}$; then 3 weeks at $22^{\circ} \mathrm{C}$, short day (SD;9-h short days). $\mathrm{CA} 1=22^{\circ} \mathrm{C}$, $\mathrm{LD}$; then 1 week at $3{ }^{\circ} \mathrm{C}, \mathrm{SD}$. CA $2=22{ }^{\circ} \mathrm{C}, \mathrm{LD}$; then 2 weeks at $22^{\circ} \mathrm{C}, \mathrm{SD}$; then 1 week at $3{ }^{\circ} \mathrm{C}, \mathrm{SD}$. $\mathrm{CA} 3=22^{\circ} \mathrm{C}, \mathrm{LD}$; then 3 weeks at $3{ }^{\circ} \mathrm{C}, \mathrm{SD}$. RampdownSD $=22^{\circ} \mathrm{C}, \mathrm{LD}$; then 1 week at $15^{\circ} \mathrm{C}, \mathrm{SD}$; then 1 week at $10^{\circ} \mathrm{C}, \mathrm{SD}$; then 1 week at $3{ }^{\circ} \mathrm{C}$, SD. RampdownLD $=22^{\circ} \mathrm{C}, \mathrm{LD}$; then 1 week at $15^{\circ} \mathrm{C}, \mathrm{LD}$; then 1 week at $10{ }^{\circ} \mathrm{C}, \mathrm{LD}$; then 1 week at $3{ }^{\circ} \mathrm{C}$, LD. Bars with the same letter are not statistically different according Fisher's least significant difference $(\alpha=0.05)$. Error bars represent SD.

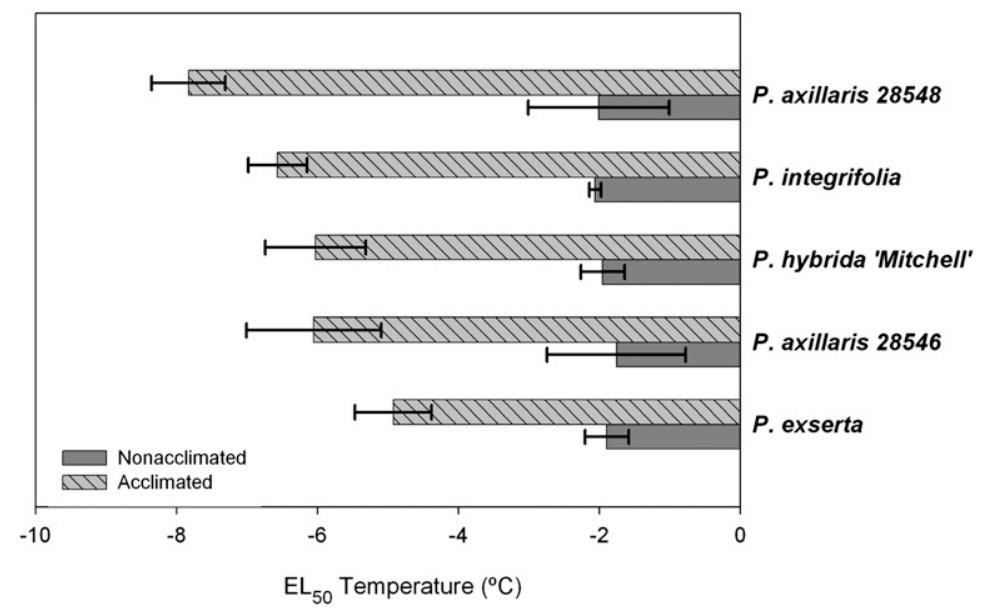

Fig. 2. Freezing tolerance $\left[\mathrm{EL}_{50}\right.$ (temperature at which $50 \%$ of maximum electrolyte leakage occurred)] for Petunia species nonacclimated $\left[7\right.$ weeks at $22{ }^{\circ} \mathrm{C}$ long day (LD)] and acclimated [6 weeks at $22{ }^{\circ} \mathrm{C} \mathrm{LD}$, 1 week at $15{ }^{\circ} \mathrm{C}$ short days (SD), 1 week at $10{ }^{\circ} \mathrm{C} \mathrm{SD}$, and 1 week at $3{ }^{\circ} \mathrm{C} \mathrm{SD}$ ]. Bars depict $\mathrm{EL}_{50}$ temperatures averaged over at least two replications for each species. Bars with the same letter are not statistically different according Fisher's least significant difference $(\alpha=0.05)$. Error bars represent SD.

temperature of $-7.8^{\circ} \mathrm{C}$, whereas $P$. exserta was the least freezing-tolerant with an $\mathrm{EL}_{50}$ temperature of $-4.9{ }^{\circ} \mathrm{C}$. In addition to the observed interspecific variation, there was also significant variation in the acclimated freezing tolerance between the two $P$. axillaris accessions. The acclimated $\mathrm{EL}_{50}$ temperatures for $P$. hybrida, $P$. axillaris (USDA accession 28546), and $P$. integrifolia are $-6.0,-6.1$, and $-6.6{ }^{\circ} \mathrm{C}$, respectively. Although there was no statistical difference in the acclimated freezing tolerance among these three species, all were all significantly less freezing-tolerant than $P$. axillaris (accession 28548) and all except $P$. axillaris (accession 28546) were more freezing-tolerant than $P$. exserta.

\section{Discussion}

Our results indicate that cool temperatures, but not reduced photoperiod, influence cold acclimation of $P$. hybrida 'Mitchell' (Fig. 1). Plants grown under long day conditions (NONLD) showed similar basal freezing tolerance levels as those exposed to a reduced photoperiod without a reduction in temperature (NONSD), indicating that in the absence of cooling, short days alone are insufficient to induce cold acclimation.
Petunia hybrida 'Mitchell' did cold-acclimate when exposed to $3{ }^{\circ} \mathrm{C}$ for 1 week along with a reduction in photoperiod from $16 \mathrm{~h}$ of light to $9 \mathrm{~h}$ (CA1), increasing in freezing tolerance by $\approx 2{ }^{\circ} \mathrm{C}$. However, freezing tolerance did not increase further with the addition of 2 weeks of exposure to short days before cold treatment (CA2) (Fig. 1). In addition, subjecting plants to gradual cooling had the same effect on cold acclimation whether under long days (Rampdown LD) or short days (Rampdown SD) with an $\mathrm{EL}_{50}$ value of $\approx-4.9{ }^{\circ} \mathrm{C}$ after either treatment. Petunia hybrida is a facultative long-day plant that exhibits a severe delay in flowering if the photoperiod is less than $14 \mathrm{~h}$ (Adams et al., 1998). Therefore, the 9-h photoperiod used as a short day in the current study should be sufficient to induce a short-day response. Because none of our photoperiod treatments influenced cold acclimation, it is unlikely that a different short photoperiod length would induce cold acclimation without a concurrent reduction in temperature.

The duration of exposure to $3{ }^{\circ} \mathrm{C}$ influenced cold acclimation (Fig. 1). Similar results were reported for Solanum commersonii in which freezing tolerance gradually increased with duration of exposure to $2{ }^{\circ} \mathrm{C}$ until a maximum was reached after $7 \mathrm{~d}$ (Pino et al., 2008). One week at $3{ }^{\circ} \mathrm{C}$ preceded by a week at $15{ }^{\circ} \mathrm{C}$ and a week at $10{ }^{\circ} \mathrm{C}$ (RampdownSD and RampdownLD) induced similar freezing tolerance as 3 weeks at $3{ }^{\circ} \mathrm{C}$ (CA3). In Arabidopsis thaliana, the level of CBF transcription is dependent on the magnitude of temperature change and the absolute temperature. With gradual cooling at a rate of $2{ }^{\circ} \mathrm{C} \cdot \mathrm{h}^{-1}$, transcripts of the cold acclimation pathway transcription factor gene family CBF become detectable in A. thaliana at temperatures as high as $14{ }^{\circ} \mathrm{C}$ with further temperature reductions increasing transcript accumulation (Zarka et al., 2003). This may help to explain why the Rampdown treatments with only 1 week at $3{ }^{\circ} \mathrm{C}$ were more effective cold acclimation regimes than 1 week at $3{ }^{\circ} \mathrm{C}$ alone (CA1), and equally effective as CA3. The initial weeks at 15 and $10{ }^{\circ} \mathrm{C}$ during the RampdownSD and RampdownLD regimes may be sufficiently cool to induce cold-acclimation pathways in petunia, allowing plants to eventually reach the same level of freezing tolerance after the final week at $3{ }^{\circ} \mathrm{C}$ as was reached after 3 weeks at $3{ }^{\circ} \mathrm{C}(\mathrm{CA} 3)$.

We examined the freezing tolerance of several wild Petunia species to identify potential genetic sources of cold tolerance for use in future breeding. All of the tested species showed similar nonacclimated freezing tolerance with an $\mathrm{EL}_{50}$ value near $-2{ }^{\circ} \mathrm{C}$ (Fig. 2). These results are consistent those of Pennycooke et al. (2003) who reported an $\mathrm{EL}_{50}$ value of $\approx-2.5{ }^{\circ} \mathrm{C}$ for nonacclimated $P$. hybrida 'Mitchell' using a slightly different electrolyte leakage assay procedure. The nonacclimated freezing tolerance of $P$. hybrida 'Mitchell' is similar to $S$. lycopersicum with an $\mathrm{EL}_{50}$ temperature of $-2{ }^{\circ} \mathrm{C}$ (Zhang et al., 2004) and S. tuberosum with an 
$\mathrm{EL}_{50}$ of $-3{ }^{\circ} \mathrm{C}$ (Pino et al., 2007). The frosttolerant species $S$. commersonii and A. thaliana ecotype RLD have nonacclimated $\mathrm{EL}_{50}$ temperatures of -5 and $-4{ }^{\circ} \mathrm{C}$, respectively (Jaglo-Ottosen et al., 1998; Pino et al., 2008). These comparisons suggest that Petunia is relatively sensitive to freezing before cold acclimation.

The two $P$. axillaris accessions showed differential cold acclimation ability (Fig. 2). These accessions also exhibited morphological differences with accession 28548 having a much longer corolla tube and leaves than accession 28546 (data not shown). Although the exact collection sites of these two accessions are unknown, they are likely different ecotypes, and differential selection pressures may have resulted in increased cold acclimation ability for accession 28548. Freezing tolerance of the species $P$. integrifolia, $P$. hybrida, and $P$. axillaris (acceession 28546) were not statistically different after acclimation with an $\mathrm{EL}_{50}$ near $-6{ }^{\circ} \mathrm{C}$. Petunia hybrida is believed to be a complex hybrid of $P$. integrifolia and $P$. axillaris (Griesbach, 2007; Sink, 1984), and P. hybrida 'Mitchell' is a hybrid of $P$. axillaris $\times(P$. axillaris $\times$ $P$. hybrida 'Rose du Ciel') (Griesbach, 2007). Therefore, it is not surprising that $P$. hybrida 'Mitchell' has cold tolerance characteristics similar to these two putative parental species.

As a point of comparison between petunia and other cold-acclimating herbaceous species, S. commersonii (Chen and Li, 1980; Pino et al., 2008) and A. thaliana ecotype RLD (Jaglo-Ottosen et al., 1998) both increase in freezing tolerance by $\approx 4{ }^{\circ} \mathrm{C}$ to reach acclimated $\mathrm{EL}_{50}$ temperatures of -9 and $-8{ }^{\circ} \mathrm{C}$, respectively. Therefore, we conclude that Petunia, and especially $P$. axillaris (accession 28548) with an acclimated $\mathrm{EL}_{50}$ temperature near $-8{ }^{\circ} \mathrm{C}$ (a $5.8{ }^{\circ} \mathrm{C}$ increase over nonacclimated plants), has the ability to cold-acclimate by a significant amount for an herbaceous species, particularly within the family Solanaceae. However, this acclimation ability is modest compared with other herbaceous species, especially grasses such as rye (Secale cereale L. sbsp. cereale) and wheat (Triticum aestivum L.), which can cold-acclimate by $15^{\circ} \mathrm{C}$ or more (Cloutier, 1983; Webb et al., 1994).

The results of these experiments indicate significant variation in the freezing tolerance of Petunia spp. after a period of cold acclimation that could be used to breed Petunia cultivars with improved freezing tolerance. Cold tolerance is a quantitative trait expected to be controlled by several genetic loci. Identification of quantitative trait loci underlying cold acclimation ability in Petunia would greatly aid implementation of marker-assisted selection to introgress cold tolerance traits from wild germplasm with superior cold ac- climation ability such as $P$. axillaris 28548 into cultivated genotypes.

\section{Literature Cited}

Adams, S.R., P. Hadley, and S. Pearson. 1998. The effects of temperature, photoperiod, and photosynthetic photon flux on the time to flowering of petunia 'Express Blush Pink'. J. Amer. Soc. Hort. Sci. 123:577-580.

Ando, T., M. Nomura, J. Tsukahara, H. Watanabe, H. Kokubun, T. Tsukamoto, G. Hashimoto, E. Marchesi, and I. Kitching. 2001. Reproductive isolation in a native population of Petunia sensu Jussieu (Solanaceae). Ann. Bot. (Lond.) 88:403-413.

Chen, H.H. and P.H. Li. 1980. Characteristics of cold acclimation and deacclimation in tuberbearing Solanum species. Plant Physiol. 65: 1146-1148.

Cloutier, Y. 1983. Changes in the electrophoretic patterns of the soluble proteins of winter wheat and rye following cold acclimation and desiccation stress. Plant Physiol. 71:400-403.

Cook, D., S. Fowler, O. Fiehn, and M. Thomashow. 2004. A prominent role for the $C B F$ cold response pathway in configuring the lowtemperature metabolome of Arabidopsis. Proc. Natl. Acad. Sci. USA 101:15243-15248.

Fowler, D.B., G. Breton, A.E. Limin, S. Mahfoozi, and F. Sarhan. 2001. Photoperiod and temperature interactions regulate low-temperature-induced gene expression in barley. Plant Physiol. 127: 1676-1681.

Griesbach, R.J. 2007. Petunia, p. 301-336. In: Anderson, N.O. (ed.). Flower breeding and genetics: Issues, challenges and opportunities for the $21 \mathrm{st}$ century. Springer, Dordrecht, The Netherlands.

Griesbach, R.J., J.R. Stehmann, and F. Meyer. 1999. Anthocyanins in the 'red' flowers of Petunia exserta. Phytochemistry 51:525-528.

Guy, C., K. Niemi, and R. Brambl. 1985. Altered gene expression during cold acclimation of spinach. Proc. Natl. Acad. Sci. USA 82:36733677.

Howell, G.S. and C.J. Weiser. 1970. The environmental control of cold acclimation in apple. Plant Physiol. 45:390-394.

Hsieh, T., J. Lee, P. Yang, L. Chiu, Y. Charng, Y. Wang, and M. Chan. 2002. Heterology expression of the Arabidopsis C-Repeat/Dehydration Response Element Binding Factor 1 gene confers elevated tolerance to chilling and oxidative stresses in transgenic tomato. Plant Physiol. 129:1086-1094.

Jaglo-Ottosen, K., S. Gilmour, D. Zarka, O Schabenberger, and M. Thomashow. 1998. Arabidopsis $C B F 1$ overexpression induces $C O R$ genes and enhances freezing tolerance. Science 280:104-106

Li, C., T. Puhakainen, A. Welling, A. ViheraAarnio, A. Ernstsen, O. Juntilla, P. Heino, and E.T. Palva. 2002. Cold acclimation in silver birch (Betula pendula). Development of freezing tolerance in different tissues and climatic ecotypes. Physiol. Plant. 116:478-488.

Marian, C.O., A. Eris, S.L. Krebs, and R. Arora. 2004. Environmental regulation of a $25 \mathrm{kDa}$ dehydrin in relation to Rhododendron cold acclimation. J. Amer. Soc. Hort. Sci. 129:354-359.

Palta, J.P., J. Levitt, and E.J. Stadelmann. 1978 Plant viability assay. Cryobiology 15:249-255.
Pennycooke, J., M. Jones, and C. Stushnoff. 2003. Down-regulating $\alpha$-galactosidase enhances freezing tolerance in transgenic petunia. Plant Physiol. 133:901-909.

Pietsch, G.M., N.O. Anderson, and P.H. Li. 2009. Cold tolerance and short day acclimation in perennial Guara coccinea and G. drummondii. Scientia Hort. 120:418-425.

Pino, M.T., J.S. Skinner, Z. Jeknic, P.M. Hayes, A.H. Soeldner, M.F. Thomashow, and T.H.H. Chen. 2008. Ectopic AtCBF1 over-expression enhances freezing tolerance and induces cold acclimation-associated physiological modifications in potato. Plant Cell Environ. 31:393406.

Pino, M.T., J.S. Skinner, E.J. Park, Z. Jeknic, P.M. Hayes, M.F. Thomashow, and T.H.H. Chen. 2007. Use of a stress inducible promoter to drive ectopic $A t C B F$ expression improves potato freezing tolerance while minimizing negative effects on tuber yield. Plant Biotechnol. J. 5:591-604.

Sink, K.C. 1984. Taxonomy, p. 3-9. In: Sink, K.C. (ed.). Monographs on theoretical and applied genetics 9: Petunia. Springer-Verlag, Berlin, Germany.

Sukumaran, N.P. and C.J. Weiser. 1972. An excised leaflet test for evaluating potato frost tolerance. HortScience 7:467-468.

Tanksley, S.D. and S.R. McCouch. 1997. Seed banks and molecular maps: Unlocking genetic potential from the wild. Science 277:10631066.

Thapa, B., R. Arora, A. Knapp, and E. Brummer. 2008. Applying freezing test to quantify cold acclimation in Medicago truncatula. J. Amer. Soc. Hort. Sci. 133:684-691.

Thomashow, M. 1999. Plant cold acclimation: Freezing tolerance genes and regulatory mechanisms. Annu. Rev. Plant Physiol. Plant Mol. Biol. 50:571-599.

U.S. Department of Agriculture-National Agricultural Statistics Service. 2008. Floriculture crops 2007 summary. 22 May 2009. <http://usda. mannlib.cornell.edu/usda/current/FlorCrop/ FlorCrop-04-24-2008.pdf>

Webb, M.S., M. Uemura, and P.L. Steponkus. 1994. A comparison of freezing injury in oat and rye: Two cereals at the extremes of freezing tolerance. Plant Physiol. 104:467478.

Wise, R.R. and A.W. Naylor. 1987. Chillingenhanced photooxidation. The peroxidative destruction of lipids during chilling injury to photosynthesis and ultrastructure. Plant Physiol. 83:272-277.

Yelenosky, G. and C. Guy. 1989. Freezing tolerance of citrus, spinach, and petunia leaf tissue. Plant Physiol. 89:444-451.

Zarka, D.G., J.T. Vogel, D. Cook, and M.F. Thomashow. 2003. Cold induction of Arabidopsis $C B F$ genes involves multiple ICE (inducer of $C B F$ expression) promoter elements and a cold-regulatory circuit that is desensitized by low temperature. Plant Physiol. 133:910-918.

Zhang, X., S. Fowler, H. Cheng, Y. Lou, S. Rhee, E. Stockinger, and M. Thomashow. 2004. Freezing-sensitive tomato has a functional $C B F$ cold response pathway, but a $C B F$ regulon that differs from that of freezing-tolerant $\mathrm{Ara}$ bidopsis. Plant J. 39:905-919. 